УДК 331.104 .22

\title{
ФОРМУВАННЯ HR-БРЕНДУ КОМПАНІЇ ТА ЙОГО ОЦІНЮВАННЯ
}

\section{FORMATION OF HR-BRAND OF THE COMPANY AND ITS EVALUATION}

\author{
Грищенко Діана Григорівна \\ кандидат економічних наук, доцент, \\ Національний університет харчових технологій \\ ORCID: https://orcid.org/0000-0002-1710-1938 \\ Йосифчук Ярослав Миколайович \\ здобувач, \\ Національний університет харчових технологій \\ ORCID: https://orcid.org/0000-0002-1470-9227 \\ Hryshchenko Diana, Yosyfchuk Yaroslav \\ National University of Food Technologies
}

\begin{abstract}
У статті розглянуто точки зору зарубіжних та вітчизняних вчених, які досліджували теоретичні і практичні аспекти формування HR-бренда. Виокремлено і проаналізовано модель, яка на думку авторів, $є$ найефективнішою. Здійснено аналіз HR-бренду ПрАТ «ОБОЛОНь» за різними методиками для отримання об'єктивних результатів. Рівень залученості персоналу як прямий індикатор стану HR-бренду компанії досліджено за допомогою опитувальника Q12. На основі комплексної авторської методики Мокіної С.М. за точками контакту, здійснено загальну оцінку та детально досліджено внутрішній та зовнішній HR-бренд. Розраховано індекс сили бренду роботодавця та побудовано діаграму і матрицю бренду роботодавця, що дозволяє виділити сорери, які потребують втручання для підвищення результативності бренда. Отримані результати можуть бути використані в теорії та практиці фрормування HR-бренду компанії.
\end{abstract}

Ключові слова: бренд роботодавця, фрормування HR-бренда, комплексна методика за точками контакту, оцінювання HR-бренда, залученість працівників.

В статье рассмотрены точки зрения зарубежных и отечественных ученых, исследовавших теоретические и практические аспекты формирования HR-бренда. Выделено и проанализировано модель, которая, по мнению авторов, является наиболее эффективной. Осуществлен анализ HR-бренда ЗАО «Оболонь» по разным методикам для получения объективных результатов. Уровень вовлеченности персонала как прямой индикатор состояния HR-бренда компании исследовано с помощью опросника Q12. На основе комплексной авторской методики Мокиной С.М. по точкам контакта, осуществлено общую оценку и подробно исследованы внутренней и внешней HR-бренд. Рассчитан индекс силы бренда работодателя и построена диаграмма и матрица бренда работодателя, что позволяет выделить сферы, требующие вмешательства для повышения результативности бренда. Полученные результаты могут быть использованы в теории и практике формирования HR-бренда компании.

Ключевые слова: бренд работодателя, фрормирование HR-бренда, комплексная методика по точкам контакта, оценивание HR-бренда, вовлеченность работников.

In times of various economic transformations and trials, every enterprise must have certain assets that would ensure economic growth. Under such conditions, the company's brand as an employer can be considered an excellent and necessary asset. Because a successful HR-brand, both internal and external, will help attract and retain the best professionals in the industry in which the company operates. The article analyzes the methodology of employer brand formation. In particular, the key models of employer brand formation are listed. The model that, according to the authors, is the most effective in the formation of a successful HR-brand is identified and analyzed. The analysis of the HR-brand of PrJSC "Obolon" was carried out according to different methods to obtain objective results. The level of staff involvement as a direct indicator of the state of the company's hr-brand was studied using the Q12 questionnaire developed by the American Institute for Public Opinion Research. Based on the complex author's method of S. Mokina at the points of contact, a general assessment was made and the internal and exter- 
nal brand of the employer was studied in detail. The index of strength of the employer's brand is calculated and the diagram and matrix of the employer's brand are constructed. The employer brand strength diagram provides a clear demonstration of the gap between the employer's external and internal brand, at each point of contact, and identifies areas that need intervention to reduce this gap and increase brand effectiveness. Thus, the Obolon HR-brand has a strong internal hr-brand, but a weak external one. The level of involvement and loyalty to the employer is at a good level, and work in the company is a positive experience, according to employees, at their points of contact with the employer. However, the external hr-brand shows that although the company is known in the labor market, but its image as an employer is negative rather than positive at certain points of contact, reviewing and making appropriate management decisions can change the current situation. The obtained results can be used in the theory and practice of forming the HR-brand of the company.

Keywords: employer brand, HR-brand building, comprehensive point-of-contact methodology, HR-brand assessment, employee engagement.

Постановка проблеми. У час різноманітних економічних транссрормацій та інтеграції України в європейський економічний простір, на українському ринку праці йде висококонкурентна боротьба за кваліфікованих спеціалістів. Тому, володіючи позитивним HR-брендом, компанія зможе залучити та утримати потрібних їй спеціалістів. Коли у компанії сильний HR-бренд, він виступає для неї своєрідним активом, який здатен забезпечити певні конкурентні переваги на ринку праці. Проте, для досягнення цього, роботодавцю необхідно всіма можливими засобами сприяти формуванню як внутрішнього, так і зовнішнього бренду, а саме ретельно вивчати успішні кейси великих іноземних компаній та ключові методики фрормування, які сьогодні відомі. Це питання потребує ретельного аналізу та розробки продуманої моделі по розбудові як внутрішнього так і зовнішнього бренду компанії як надійного та привабливого роботодавця.

Аналіз останніх досліджень і публікацій. Питання формування бренду компанії як роботодавця розглядали у своїх працях С. Берроу, Д. Аакер, Дж. Вічманн, Б. Ванекен, Л. Сартен, Дж. Грегорі та інші. Серед українських науковців питання, що стосувались брендингу роботодавця досліджували А.Войчак, О. Ляшенко, Р. Федорович, О. Кістень, А. Старостіна та інші [1-8]. Проте, розуміння концепції бренду роботодавця не має єдиного теоретичного підходу, що ускладнює його аналіз та подальшу розробку ефективних порад вітчизняним підприємствам для формування їх власного HR-бренда. Слід також зазначити, що у поданих працях не було у повній мірі розглянуто питання впливу Hr-бренда компанії на рівень залученості персоналу, а також питання його оцінювання.

Метою статті $€$ дослідження методик формування HR-бренду та апробація підходів щодо оцінки бренда роботодавця і залученості працівників, зіставлення та порівняння результатів.
Викладення основних результатів дослідження. Сьогодні існує велика кількість різноманітних моделей фрормування бренда роботодавця. Зокрема відомими сьогодні $€$ : 4D площина бренда роботодавця за T. Гедом; модель капіталу бренда роботодавця; концептуальна модель розуміння бренда роботодавця за К. Бакхаусом і С. Тікоо; модель екосистеми бренда роботодавця за Б. Мінчінгтоном та піраміда бренда роботодавця за П. Бурке. Особливої уваги, серед моделей формування бренда роботодавця, заслуговує модель екосистеми бренда роботодавця за Б. Мінчінгтоном, зображена на рис 1, адже в ній, на відміну від інших моделей, наведено не лише прямі інструменти фрормування бренду роботодавця, а також i зовнішні тенденції, які теж слід враховувати успішному роботодавцеві $[4 ; 5 ; 8]$.

Модель екосистеми бренда роботодавця за Б. Мінчінгтоном, має шість складових. Першою її складовою $є$ цінності бренда роботодавця, які можуть бути: цифровими, друкованими та звуковими, а також безпосередньо представниками бренду. Друга складова моделі включає у себе основні інструменти бренда роботодавця, які поділені на тактичні інструменти, тобто програми з підбору, адаптації, розвитку, кар'єри, пільг, а також стратегічні інструменти, які включають корпоративну культуру, корпоративну соціальну відповідальність та інновації. Третя складова $\epsilon$ капіталом бренда роботодавця, і ділиться на фрізичну доступність бренда, тобто відгуки у соцмережах, подкасти, тематичні журнали, ярмарки вакансій, та ментальну у вигляді уявлень працівників про переваги зайнятості в компанії, асоціації з брендом роботодавця та лояльність до нього. Наступними є учасники у галузі промисловості, в якій працює компанія, і які впливають на бренд роботодавця, тобто блогери, ЗМІ, науковці та інші. Далі іде управління життєвим циклом, притаманне всім співробітникам незалежно від стадії їх контакту з компанією, яке включає ряд етапів 


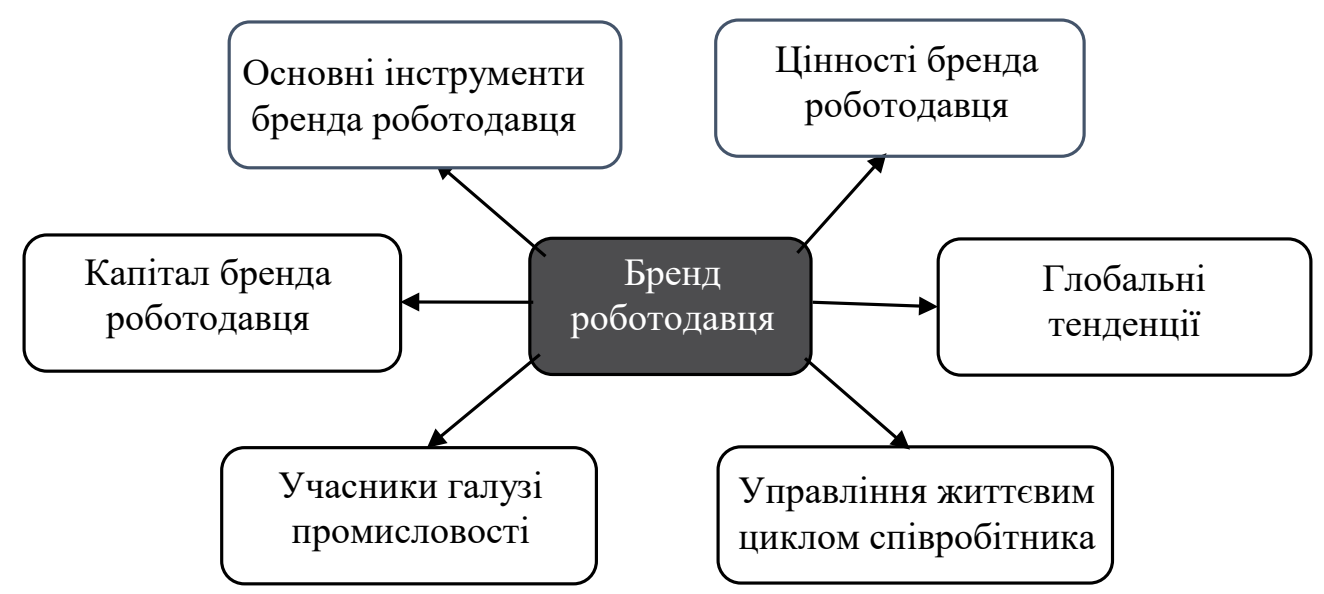

Рис. 1. Модель екосистеми бренда роботодавця за Б. Мінчінгтоном

від найму до звільнення. I останньою, шостою складовою моделі, $є$ глобальні тенденції, які розділено на політичні, соціальні, економічні та технологічні [6].

Асоціації бренда роботодавця це ті образи, ідеї та думки, які виникають у потенційних та вже працюючих співробітників при згадуванні назви компанії, наприклад це може бути висока заробітна плата, чи хороший розвиток і кар'єрний ріст для срахівця, або ж керівництво яке надихає своїх працівників щодня і де панує неповторна корпоративна культура. Лояльність до бренда роботодавця, виникає 3 попередньої складової, а точніше асоціацій, адже ці позитивні асоціації і примушують першокласних фрахівців працювати саме в цій компанії, а не в іншій, фрормують прихильність до цього роботодавця. Як бачимо, капітал бренда це не що інше як стратегічний актив необхідний компанії як роботодавцю, для залучення та утримання в себе висококваліфрікованих фрахівців [3].

Найпоширенішим способом оцінки залученості $€$ опитувальники. Зокрема найбільш достовірним та об'єктивним вважається опитувальник Gallup Q12. (розроблений американським інститутом дослідження громадської думки). Він включає у себе 12 запитань, які вимірюють найбільш важливі елементи залученості співробітників [2]:

1) Чи знаєте ви, чого очікує від вас роботодавець?

2) У вас $є$ матеріали та інструменти, необхідні для якісної роботи?

3) У вас $є$ можливість кожен день робити те, що ви вмієте найкраще?

4) За останні сім днів чи отримували ви визнання або похвалу за хорошу роботу?
5) Чи вважаєте ви, що ваш керівник або хтось на роботі піклується про вас як про особистість?

6) Хто-небудь на роботі сприяє вашому розвитку?

7) Чи враховується ваша точка зору?

8) Місія і мета вашої компанії змушує вас відчувати, що ваша робота важлива?

9) Чи вважають ваші колеги своїм обов'язком якісно виконувати свою роботу?

10) У вас $є$ найкращий друг на роботі?

11) За останні пів року хтось на роботі говорив з вами про ваші успіхи?

12) Минулого року у вас були можливості вчитися і рости на роботі?

Згідно методики, залученість персоналу розраховується за фрормулою [2]:

$$
\frac{\text { Кількістьвідповідей «так» } 100 \%}{\text { загальнукількістьвідповідей }}=\% \text { залученості }
$$

Високим рівень залученості вважається тоді, коли він перевищує 70\%, задовільним коли становить більше 50\% [2].

Дослідивши залученість працівників як індикатор лояльності до бренду роботодавця було отримано наступний результат: загальний показник залученості персоналу ПрАТ "Оболонь" складає 62\%, тобто є задовільним. Проте його можна збільшити до $70 \%$ або й більше, переглянувши ті моменти, які перешкоджають кращій залученості персоналу.

Наступною, для оцінки бренду компанії як роботодавця, пропонується використати комплексну авторську методику оцінювання бренда роботодавця Мокіної С.М., за точками контакту, яка була складена на основі концепції контактного брендингу С. Девіса і М. Данна, та моделі оцінювання товарного бренду Л. де Чернатоні [5]. 
Методика передбачає розгляд 15 основних точок контактів спеціаліста 3 роботодавцем, від найму, та тому що йому передує, і до звільнення, або завершення роботи в компанії. На їх основі, пропонується дослідження, яке проводиться в чотири етапи: збір зовнішньої індрормації, тобто опитування кандидатів на посаду в компанії, збір внутрішньої інфрормації, тобто опитування серед вже працюючих, аналіз отриманих даних та розроблення відповідних рішень по вирішенню існуючих проблем, і фрормування позитивного бренду роботодавця, як внутрішнього так і зовнішнього [5].

Було представлено 50 питань які стосувались кожної з 15 точок контакту роботодавця з працівниками та потенційними кандидатами. На ці питання респонденти (51 чол., з яких 35 чол. - працівники компанії та 16 чол. - потенційні кандидати) відповідали, за розробленою Мокіною С. М. лінгвістично-бальною шкалою, від -3 до +3. Шкала наведена в табл. 1 [5].

Таблиця 1

Лінгвістично-бальна шкала оцінювання бренду роботодавця в результаті анкетування спеціалістів

\begin{tabular}{|c|c|}
\hline Бали & Інтерпретація \\
\hline-3 & Категорично не згоден \\
\hline-2 & Не згоден \\
\hline-1 & Скоріше не згоден \\
\hline 0 & Важко відповісти/Не відомо \\
\hline 1 & Скоріше згоден \\
\hline 2 & Згоден \\
\hline 3 & Повністю згоден \\
\hline
\end{tabular}

За методикою Мокіної С.М., пропонується отримати кількісний показник, на основі анкетування, а саме індекс сили бренду роботодавця, I ІвР, який розраховуємо окремо для зовнішнього і окремо дня внутрішнього HR-брендів, за фрормулою [5]:

$I_{E B P}=P_{7}+\left(P_{6}-P_{2)^{*}} 0,6667+\left(P_{5}-P_{3)^{*}} 0,333+P_{4^{*}} 0-P_{1}(2)\right.\right.$

де $\mathrm{P}_{1}$ - частка респондентів, що дали відповідь «категорично не згоден»;

$\mathrm{P}_{2}$ - частка респондентів, що дали відповідь «не згоден»;

$\mathrm{P}_{3}$ - частка респондентів, що дали відповідь «частково не згоден»;

$\mathrm{P}_{4}$ - частка респондентів, що дали відповідь «важко відповісти/не відомо»;

$\mathrm{P}_{5}$ - частка респондентів, що дали відповідь «скоріше згоден»;

$\mathrm{P}_{6}$ - частка респондентів, що дали відповідь «згоден»;

$\mathrm{P}_{7}$ - частка респондентів, що дали відповідь «повністю згоден».

Розрахувавши зовнішній $\mathrm{I}_{\text {Евр }}$ для ПрАТ «ОБОЛОНЬ» було отримано значення

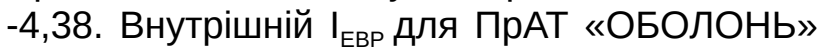
становить 47,06. На основі цих розрахунків, було також ссрормовано діаграму сили бренду роботодавця ПрАТ «ОБОЛОНЬ» (рис. 2).

Отримане значення внутрішнього $\mathrm{I}_{\text {ЕВР }}$ ПрАТ «ОБОЛОНЬ» свідчить про хороший внутрішній бренд роботодавця, проте зовнішній IEBP, показує від'ємне значення. Отже, у потенційних кандидатів, згідно даних проведеного дослідження, складається негативний образ компанії як роботодавця, в той час як лояльність вже працюючих працівників є задовільною.

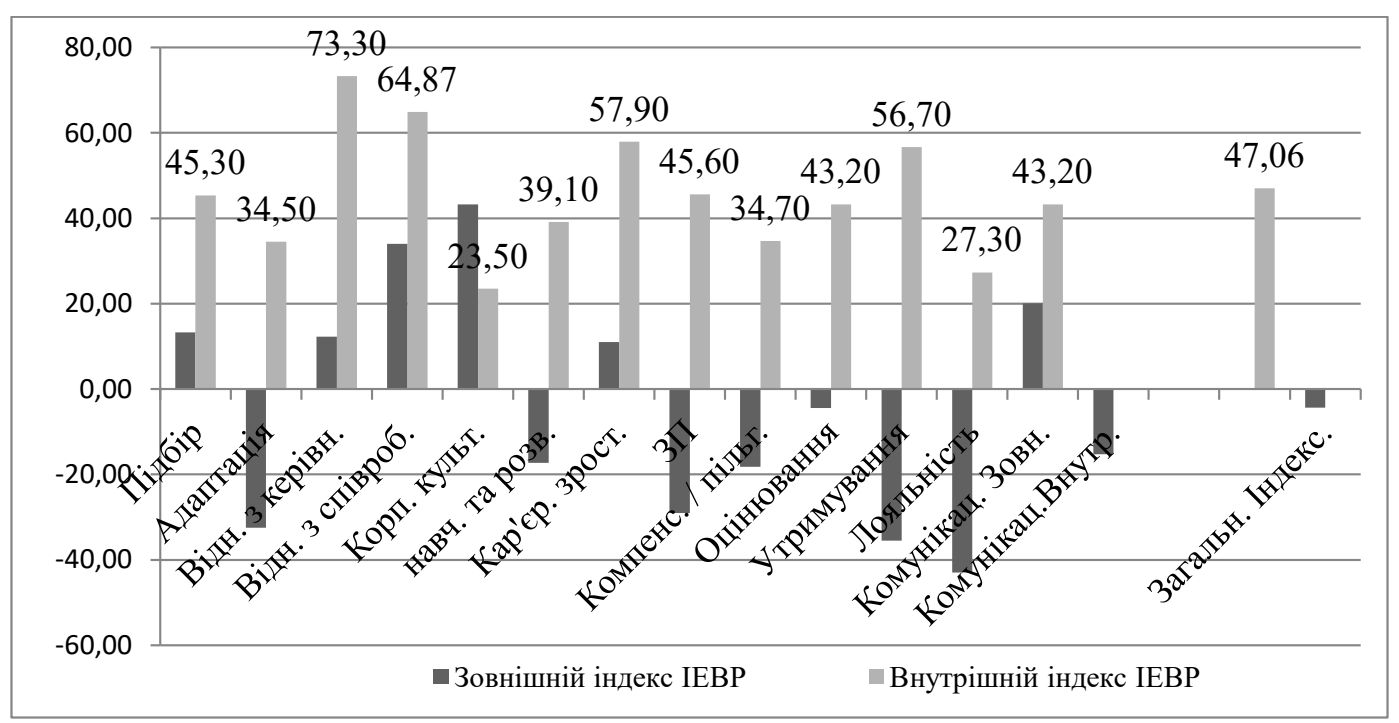

Рис. 2. Діаграма сили бренду ПрАТ «ОБОЛОНь» як роботодавця 


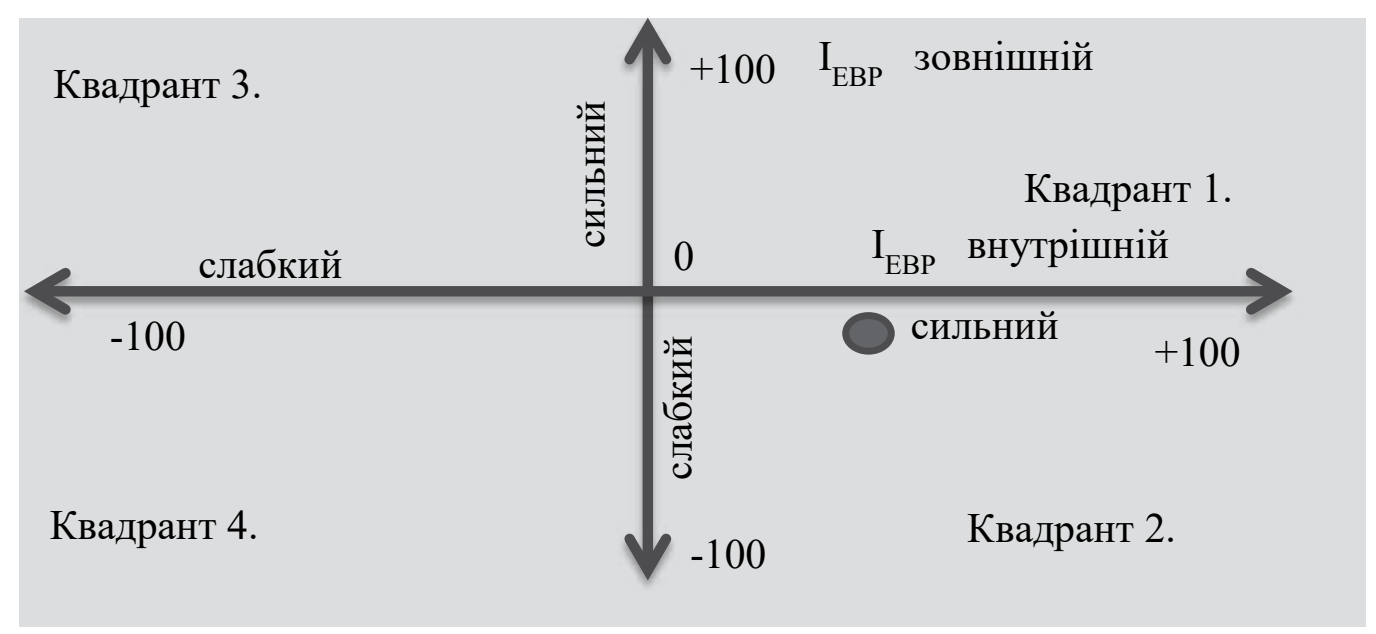

Рис. 3. Матриця сили бренду ПрАТ «ОБОЛОНЬ» як роботодавця

Джерело: розраховано автором

Заключним етапом аналізу за методикою точок контактів, є побудова матриці сили бренду роботодавця, яка дозволить компанії, в подальшому, працювати над розвитком та управлінням її бренду як роботодавця (рис. 3).

Отже, як бачимо 3 поданої матриці сили бренду роботодавця, ПрАТ «ОБОЛОНь» як роботодавець, потрапляє у Квадрант 2. 3 цього виходить, що внутрішній HR-бренд $€$ сильним, що також підтверджують дані отримані за опитувальником Gallup Q12. Тому основну увагу слід звернути на фрормування зовнішнього HR-бренда. Для покращення зовнішнього бренду компанії як роботодавця, який $\epsilon$ досить слабким, можна запропонувати створення кар'єрного сайту. Кар'єрний сайт сприятиме формуванню привабливого зовнішнього бренду, а отже, дозволить вирішувати проблеми залучення талантів. Також, завдяки підвищенню зацікавленості співробітників у роботодавці, сприятиме покращенню внутрішнього бренду. Все це сприятиме як посиленню вже наявних внутрішніх переваг роботодавця, так і формуванню таких потрібних для компанії, зовнішніх переваг, тобто фрормування образу компанії як хорошого роботодавця.
Висновки. В результаті дослідження було визначено існування ряду методик щодо формування бренду компанії як роботодавця. Проте, найефрективнішою, на думку авторів, $є$ модель екосистеми за Б. Мінчінгтоном, оскільки у ній враховано значно більше аспектів, необхідних для формування успішного HR-бренда.

Застосована в дослідженні бренду роботодавця, комплексна методика Мокіної С.М., за точками контакту, дозволяє отримати кількісні показники, які показують загальну тенденцію розвитку HR-бренда, a побудована на іiї основі діаграма сили бренду, вказує на ключові моменти на які слід звернути увагу при його покращенні або формуванні. Даний підхід було апробовано на прикладі дослідження HR-бренда ПрАТ «ОБОЛОНь». Крім того дослідження стану внутрішнього HR-бренда ПраТ «Оболонь» було проведено і за методикою американського інституту Геллапа Q12. Незважаючи на відмінність використаних методик між собою, було отримано схожі результати розрахунків, що свідчить про достовірність наведених даних.

\section{СПИСОК ВИКОРИСТАНИХ ДЖЕРЕЛ:}

1. Васьків Р.І. Місце бренду роботодавця в загальному брендингу компанії. Науковий вісник НЛтУ України. 2014. № 24(6). С. 169-175.

2. Залученість персоналу: Gallup Q12. URL: https://hurma.work/blog/zaluchenist-personalu-gallup-q12spisok-pitan/ (дата звернення: 30.04.2021).

3. Лозовський O.M. HR-брендинг: формування іміджу підприємства. Економіка та управління підприємствами. 2020. № 43. С. 201-205.

4. Мокіна С.М. Концепція бренду роботодавця: сутність, функції, класифікація, інструменти формування. Вісник Хмельницького національного університету. 2014. № 6. Т. 1. С. 189-196. 
5. Мокіна С.М. Моделі формування бренда роботодавця. Бізнесінфрорм. 2014. № 7. С. 389-398.

6. Мокіна С.М. Методика оцінювання сили бренду роботодавця за точками контакту. Інноваційна економіка. 2014. № 1. С. 132-145.

7. Писаревська Г.І., Аграмакова Н.В., Семенченко А.В. HR-брендинг як складова бізнес стратегії підприємства. Економічні науки. 2019. № 33. С. 176-180.

8. Синиця С.М., Вакун О.В., Фурса Т.П. Особливості фрормування іміджу підприємства як чинник конкурентоспроможності на зовнішніх ринках. Економіка та управління підприємствами. 2019. № 38(1). С. 147-151.

\section{REFERENCES:}

1. Vaskiv R.I. (2014). Mistse brendu robotodavtsya v zahal'nomu brendynhu kompaniyi [The place of the employer's brand in the overall branding of the company]. Scientific Bulletin of NLTU of Ukraine, no. 24(6), pp. 169-175.

2. Zaluchenist personalu: Gallup Q12 [Staff involvement: Gallup Q12]. Available at: https://hurma.work/blog/ zaluchenist-personalu-gallup-q12-spisok-pitan/ (accessed 30 April 2021).

3. Lozovskyy O.M. (2020). HR-brendynh: formuvannya imidzhu pidpryyemstva [HR-branding: the formation of the image of the enterprise. Economics and business management]. Ekonomika ta upravlinnia pidpryiemstvamy, no. 43 , pp. 201-205

4. Mokina S.M. (2014). Kontseptsiya brendu robotodavtsya: sutnist', funktsiyi, klasyfikatsiya, instrumenty formuvannya [The concept of the employer's brand: the essence, functions, classification, tools of formation]. Bulletin of Khmelnytsky National University, no. 6, t. 1, pp. 189-196.

5. Mokina S.M. (2014). Modeli formuvannya brenda robotodavtsya [Models of employer brand formation]. Busines-sinform, no. 7, pp. 389-398.

6. Mokina S.M. (2014). Metodyka otsinyuvannya syly brendu robotodavtsya za tochkamy kontaktu [Methods for assessing the strength of the employer's brand by points of contact]. Innovative economy, no. 1, pp. 132-145.

7. Pisarevska G.I. (2019). HR-brendynh yak skladova biznes stratehiyi pidpryyemstva [Agramakova N.V., Semenchenko A.V. HR-branding as a component of business strategy of the enterprise]. Economic sciences, no. 33, pp. 176-180.

8. Sinitsa S.M., Vakun O.V., Fursa T.P. (2019).Osoblyvosti formuvannya imidzhu pidpryyemstva yak chynnyk konkurentospromozhnosti na zovnishnikh rynkakh [Features of enterprise image formation as a factor of competitiveness in foreign markets]. Economics and business management, no. 38(1), pp. 147-151. 